\title{
STUDI PENGGUNAAN PRODUK KIMIA DAN BIOLOGI PADA BUDIDAYA UDANG VANAME (Litopenaeus vannamei) DI TAMBAK KABUPATEN PESAWARAN PROVINSI LAMPUNG
}

\author{
Akhmad Mustafa, Irmawati Sapo, dan Mudian Paena \\ Balai Riset Perikanan Budidaya Air Payau \\ Jl. Makmur Dg. Sitakka, Maros, Sulawesi Selatan 90511 \\ E-mail: akhmadmustafa@yahoo.com
}

(Naskah diterima: 5 Agustus 2009; Disetujui publikasi: 25 Januari 2010)

\begin{abstract}
ABSTRAK
Kemerosotan kualitas lingkungan menyebabkan terjadinya serangan penyakit udang vaname (Litopenaeus vannamei), sehingga penggunaan produk kimia dan biologi menjadi penting sebagai konsekuensi dalam mempertahankan produksi di tambak. Oleh karena itu, studi ini dilakukan untuk mengetahui produk kimia dan biologi yang digunakan di tambak udang vaname Kabupaten Pesawaran Provinsi Lampung sebagai upaya awal untuk mengantisipasi dampaknya terhadap lingkungan. Produk kimia dan biologi serta karakteristik budidaya tambak diketahui melalui pengajuan kuisioner secara terstruktur kepada responden di 29 usaha budidaya tambak di Kecamatan Padang Cermin dan Punduh Pidada Kabupaten Pesawaran. Pengukuran dan pengambilan contoh air dilakukan pada siklus hujan dan kemarau. Statistik deskriptif digunakan untuk mengetahui gambaran umum data penggunaan produk kimia dan biologi serta kualitas air. Uji-T digunakan untuk mengetahui perbedaan karakteristik budidaya tambak intensif dan super-intensif. Hasil studi menunjukkan bahwa ada 48 jenis produk kimia dan biologi yang digunakan di tambak dan dapat dibagi atas 5 kelompok yaitu: disinfektan, pestisida, pupuk, perbaikan tanah, dan air serta tambahan pakan yang masing-masing dibagi lagi menjadi beberapa sub-kelompok. Pestisida organik dan kapur adalah sub-kelompok produk yang banyak digunakan dan sebaliknya pestisida anorganik adalah sub-kelompok produk yang paling sedikit digunakan di tambak udang vaname. Produk kimia dan biologi yang bersifat sangat beracun, sulit terurai, dapat terakumulasi dalam tubuh organisme dan berbahaya bagi keselamatan makanan ternyata tidak digunakan dalam budidaya tambak udang vaname. Dengan berdasar pada produksi dan luasan tambak udang vaname intensif dan super-intensif maka dihasilkan beban limbah sebesar $21.349-35.582 \mathrm{~kg} \mathrm{~N}$ dan $3.050-6.100 \mathrm{~kg} \mathrm{P}$ pada setiap siklus budidaya yang memiliki potensi sebagai pencemar untuk budidaya udang vaname itu sendiri di Kabupaten Pesawaran.
\end{abstract}

KATA KUNCl: kimia, biologi, udang, tambak, Lampung

ABSTRACT: Study on the use of chemical and biological products in whiteleg shrimp (Litopenaeus vannamei) culture in brackishwater ponds of Pesawaran Regency Lampung Province. By: Akhmad Mustafa, Irmawati Sapo, and Mudian Paena

Decreasing environment quality has caused disease out-breaks on whiteleg shrimp (Litopenaeus vannamei) culture, therefore, the use of chemical and biological products become important for maintaining production in brackishwater ponds. This study was conducted to know chemical and biological products used in the brackishwater pond for whiteleg shrimp culture of Pesawaran Regency Lampung 
Province as an initial effort to anticipate its impact on the environment. Chemical and biological products along with brackishwater pond characteristics were determined through questionnaires submission to respondents in 29 of whiteleg shrimp farming in Padang Cermin and Punduh Pidada Sub-districts, Pesawaran Regency. Measuring and sampling of water were carried out in rainy and dry seasons. Descriptive statistic was used to assess the general practices of chemical and biological products application as well as water quality. The t-test was used to know the differences between characteristics of intensive system and super-intensive system. Result of the study shows that there are 48 of chemical and biological products used in the brackishwater ponds. Those products can be classified into 5 groups namely: desinfectant, pesticide, fertilizer, soil and water improvement along with feed additives. Organic pesticide and lime are sub-groups dominantly used, while inorganic pesticide sub-group is the least used in the brackishwater pond for whiteleg shrimp culture. Chemical and biological products having characterics as very toxic, nonbiodesirable, accumulated in the body of aquatic organism and have impact on the food safety are not used in the brackishwater ponds for whiteleg shrimp culture. Based on the production level and brackishwater pond area of intensive and superintensive systems in Pesawaran Regency, a total of effluent load of $21,349-35,582 \mathrm{~kg}$ $N$ and 3,050-6,100 kg P per cycle were produced. It has the potential to self-pollute whiteleg shrimp culture in the brackishwater pond of Pesawaran Regency.

\section{KEYWORDS: chemical, biological, shrimp, brackishwater ponds, Lampung}

\section{PENDAHULUAN}

Pertengahan tahun 1990-an merupakan puncak keberhasilan budidaya udang windu (Penaeus monodon) di Indonesia dan sejak tahun 1996 terjadi penurunan produksi sebagai akibat serangan penyakit dan kemerosotan kualitas lingkungan. Dalam upaya mempertahankan produksi udang di Indonesia, maka diupayakan pencarian alternatif komoditas dari udang laut lainnya yang diharapkan dapat tahan terhadap serangan penyakit dan kualitas lingkungan yang rendah. Setelah melalui serangkaian kajian, akhirnya melalui SK Menteri Kelautan dan Perikanan RI No. 41/2001, pemerintah secara resmi melepas udang vaname (Litopenaeus vannamei) sebagai varietas unggul untuk dibudidayakan oleh pembudidaya tambak di Indonesia pada tanggal 12 Juli 2001 . Udang vaname disebut sebagai varietas unggul karena dinilai memiliki beberapa kelebihan antara lain: lebih tahan terhadap penyakit, tumbuh lebih cepat, tahan terhadap fluktuasi kondisi lingkungan, lama pemeliharaan relatif singkat, sintasan tergolong tinggi, dan lebih hemat pakan. Tingkat produktivitas udang vaname tergolong tinggi karena dapat memanfaatkan seluruh badan air dan dapat dipelihara dalam tambak dengan padat penebaran tinggi.

Pada tahun 2002, Indonesia mencapai kejayaan produksi udang vaname. Produksi udang vaname digambarkan "serba 70", yaitu harga benur Rp 70/ekor dengan kemampuan menghasilkan udang ukuran 70 ekor/kg dengan lama pemeliharaan 70 hari. Setelah itu, serangan penyakit terhadap udang vaname mulai terjadi yang kemudian menurunkan produksi udang nasional, dan khusus di Provinsi Lampung dan Jawa Timur penurunan produksi mencapai $40 \%$ pada awal tahun 2009. Pemerintah berusaha mengantisipasi serangan penyakit terhadap udang vaname dengan memperbaharui varietas induk udang yang lebih tahan penyakit. Pada Mei 2009, pemerintah meluncurkan induk udang unggul Vaname Nusantara I yang merupakan persilangan induk vaname asal Florida, Amerika Serikat, dan induk lokal dengan rata-rata sintasan benihnya dapat mencapai $83 \%$. Di lain pihak, untuk dapat mempertahankan produksinya, banyak pembudidaya udang vaname menggunakan produk kimia dan biologi mulai dari persiapan tambak sampai panen. Secara umum, penggunaan produk kimia dan biologi dalam akuakultur untuk meningkatkan produktivitas alami, mempertahankan peubah fisika-kimia yang optimum untuk pertumbuhan organisme yang dibudidayakan dan mencegah serta sebagai perlakuan terhadap masalah penyakit (Subasinghe et al., 2000; Cruz-Lacierda et al., 2008). Dalam akuakultur, seperti halnya dengan semua sektor yang memproduksi makanan, salah satu masukan eksternal yang 
dibutuhkan untuk keberhasilan produksi adalah produk kimia dan biologi (Subasinghe et al., 2000). Namun demikian, penggunaan produk kimia dan biologi ini perlu pula diwaspadai sebab memiliki potensi dampak lingkungan dan kesehatan manusia (Gräslund \& Bengtsson, 2001; Gräslund et al., 2003).

Primavera (1993) telah melakukan survai mengenai penggunaan produk kimia dan biologi pada budidaya udang windu di Visayas Barat dan Mindanao Timur, Filipina. Hal yang sama juga telah dilakukan di budidaya tambak Thailand (Tonguthai, 2000; Gräslund et al., 2003). Di tambak udang windu sistem ekstensif, Alam (2007) telah melakukan survai untuk mengetahui produk kimia dan biologi yang digunakan di tambak yang terletak di barat daya Banglades. Juga telah dilakukan survai mengenai penggunaan produk kimia dan biologi untuk tambak budidaya udang windu dan ikan bandeng (Chanos chanos) dan polikultur keduanya di seluruh Filipina (CruzLacierda et al., 2000; 2008). Selanjutnya LyleFritch et al. (2006) telah melakukan survai mengenai penggunaan produk kimia dan biologi pada budidaya udang vaname di Sinaloa, Meksiko. Untuk penggunaan produk kimia saja di tambak udang juga telah dilaporkan oleh Phillips (2000) di Banglades, Kamboja, Srilanka, dan Vietnam; Pathak et al. (2000) di India; Yulin (2000) di Cina; Shariff et al. (2000) di Malaysia dan Singapura serta Supriyadi \& Rukyani (2000) di Indonesia. Untuk menambah informasi ini khususnya di Indonesia untuk budidaya udang vaname, maka juga telah dilakukan studi penggunaan produk kimia dan biologi untuk budidaya udang vaname di Kabupaten Pesawaran Provinsi Lampung. Provinsi Lampung merupakan salah satu sentra produksi budidaya tambak termasuk budidaya udang vaname di Indonesia. Sekitar 25\% produksi budidaya tambak di Indonesia berasal dari Provinsi Lampung pada tahun 2006. Studi yang dilakukan di Kabupaten Pesawaran ini adalah merupakan usaha untuk mengetahui penggunaan produk kimia dan biologi dalam budidaya udang vaname sebagai upaya awal untuk mengantisipasi dampaknya terhadap lingkungan serta mendukung usaha Pemerintah (Keputusan Menteri Kelautan dan Perikanan No. KEP.02/MEN/2007) bahwa produk perikanan budidaya Cara Budidaya Ikan yang Baik (CBIB) adalah bebas dari cemaran biologi, kimia, dan fisika.

\section{BAHAN DAN METODE}

Studi diawali melalui pertemuan dengan staf Dinas Kelautan dan Perikanan Kabupaten Lampung Selatan (sekarang ini lokasi studi termasuk Kabupaten Pesawaran) untuk mendapatkan informasi mengenai usaha budidaya udang vaname di Kabupaten Lampung Selatan dan dilakukan pada tahun 2007. Lokasi studi adalah di 22 usaha budidaya udang vaname di Kecamatan Padang Cermin (usaha budidaya tambak nomor 1 sampai dengan 22) dan di 7 usaha budidaya tambak di Kecamatan Punduh Pidada (usaha budidaya tambak nomor 23 sampai dengan 29) (Gambar 1).

Metode pengumpulan data yang diaplikasikan adalah metode survai, termasuk untuk mendapatkan data primer dari berbagai karakteristik usaha budidaya tambak melalui pengajuan kuisioner kepada responden secara terstruktur (Wirartha, 2006). Data diperoleh langsung di lokasi budidaya tambak dari teknisi atau manajer atau pemilik dari setiap usaha budidaya tambak udang vaname. Rasio konversi pakan, selain diperoleh langsung dari responden juga diketahui dengan menggunakan rumus yang dikemukakan oleh Parker (1987) yaitu:

$$
R K P=\frac{f}{b}
$$

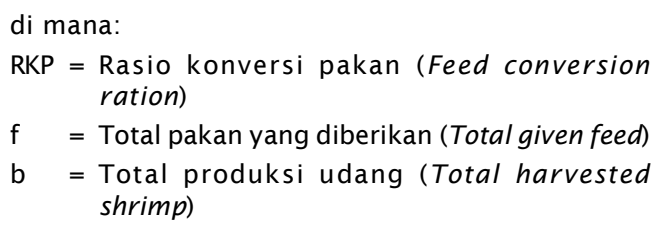

Peubah kualitas air yang diukur langsung di lapangan adalah salinitas, suhu, $\mathrm{pH}$, dan oksigen terlarut dengan menggunakan Hydrolab ${ }^{\star}$ Minisonde yang dilakukan antara pukul 09.00 dan 15.00. Pengambilan contoh air dilakukan pada tiga titik untuk setiap petak tambak dan dikomposit, sedangkan contoh air lainnya diambil pada saluran pemasukan maupun pengeluaran dan selanjutnya dipreservasi mengikuti petunjuk APHA (2005). Nitrat dianalisis dengan metode reduksi kadmium (cadmium reduction method), amonium dengan metode fenat (phenate method) dan fosfat dengan metode asam askorbik (ascorbic acid method) (APHA, 2005). Pengukuran dan pengambilan contoh air 


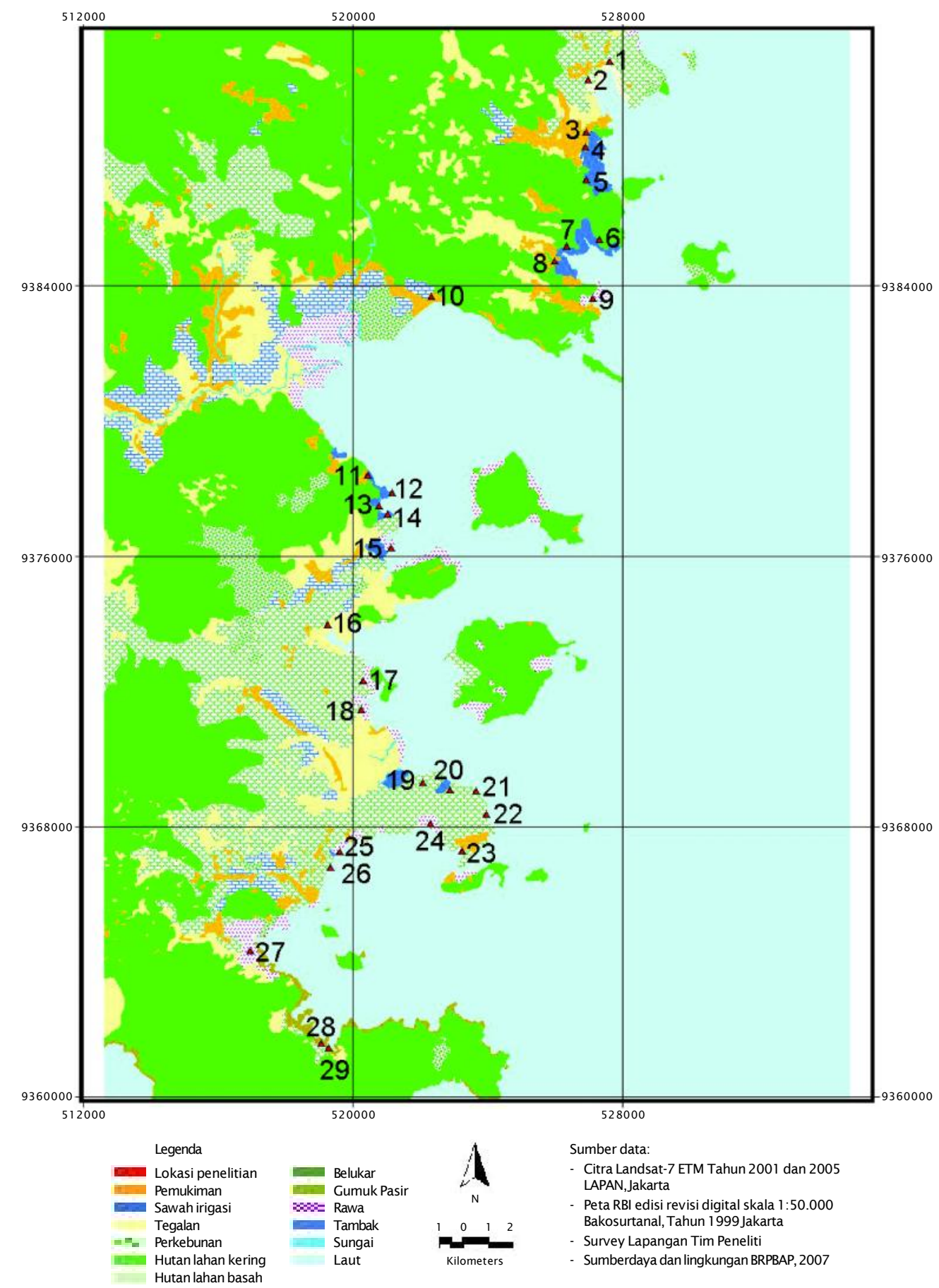

Gambar 1. Lokasi studi di tambak budidaya udang vaname (L. vannamei) di Kabupaten Pesawaran Provinsi Lampung

Figure 1. Study sites in the brackishwater pond areas of whiteleg shrimp (L. vannamei) culture in Pesawaran Regency Lampung Province 
dilakukan dua kali yaitu pada saat musim kemarau dan musim hujan untuk mendapatkan gambaran kualitas air tahunan.

Statistik deskriptif berupa rata-rata, kisaran, dan simpangan baku digunakan untuk mendapatkan informasi umum dari data yang ada. Data karakteristik tambak yang ada juga dibedakan atas sistem budidaya yang berdasarkan padat penebaran yang diaplikasikan dengan mengacu pada kriteria dari Lyle-Fritch et al. (2006). Uji-T untuk dua contoh bebas dari sistem budidaya yang berbeda digunakan untuk mengetahui perbedaan karakteristik tambak antara sistem budidaya udang intensif dan super-intensif. Taraf signifikansi dari statistik ditetapkan pada $\mathrm{P}<0,05$. Data dianalisis dengan bantuan Program Statistical Product and Service Solution (SPSS) 15,0 (SPSS, 2006; Coakes et al., 2008).

\section{HASIL DAN BAHASAN}

Tambak yang digunakan untuk budidaya udang vaname di kawasan pantai selatan Kabupaten Pesawaran umumnya dibangun di kawasan supratidal, bahkan di kawasan perbukitan yang dikonstruksi dengan teknik potong dan isi (cut and fill). Budidaya udang vaname umumnya berlokasi di daerah bukan lahan pasang surut agar pengeringan dapat dilakukan secara sempurna serta dapat dikeringkan dan dipersiapkan pada setiap penebaran (FAO, 2009). Ada juga tambak yang dibangun di kawasan intertidal yang merupakan tanah sulfat masam atau tanah gambut yang selanjutnya dilapisi dengan tanah yang berasal dari kawasan perbukitan. Beberapa tambak juga dibangun pada tanah yang tergolong tanah gambut. Pada tahun 2007 dijumpai 29 usaha budidaya tambak udang vaname yang beroperasi di Kecamatan Padang Cermin dan Punduh Pidada Kabupaten Pesawaran atau $71 \%$ dari total usaha budidaya tambak udang vaname (41 usaha budidaya tambak) yang terdaftar pada Dinas Perikanan dan Kelautan Kabupaten Lampung Selatan. Berdasarkan kriteria yang dikemukakan oleh Lyle-Fritch et al. (2006) bahwa sistem budidaya udang vaname tergolong intensif apabila kepadatannya antara 30 dan 150 ekor/m², maka dijumpai 18 usaha budidaya udang intensif dan sisanya tergolong budidaya udang superintensif. Sistem budidaya intensif adalah sistem budidaya udang vaname yang umum di Asia dan di beberapa tempat di Amerika Latin (FAO, 2009).
Kemerosotan kualitas lingkungan dan berkembangnya serangan penyakit pada tambak udang vaname, berdampak pada perlunya upaya mempertahankan produksi udang vaname di Kabupaten Pesawaran adalah merupakan penyebab penggunaan produk kimia dan biologi di tambak. Selain itu, produk kimia dan biologi juga digunakan sebagai produk yang sudah biasa digunakan di tambak atau sudah merupakan standar prosedur operasional dalam budidaya udang di tambak. Seperti halnya di bidang pertanian, penggunaan produk kimia dan biologi adalah "ramuan" yang esensial untuk keberhasilan pada bidang akuakultur telah digunakan dengan jenis produk berbeda di berbagai negara (Subasinghe et al., 2000). Di Kabupaten Pesawaran, ditemukan 48 jenis produk yang digunakan di tambak udang vaname (Tabel 4). Jumlah jenis produk yang didapatkan ini lebih banyak daripada yang ditemukan oleh Alam (2007) yang melaporkan penggunaan 5 jenis produk di tambak tradisional Banglades dan Primavera (1993) yang mendokumentasikan 40 jenis produk yang digunakan di tambak Filipina. Namun demikian, jumlah jenis ini lebih sedikit dibandingkan dengan temuan Gräslund et al. (2003) (lebih dari 290 jenis produk), LyleFritch et al. (2006) (106 jenis produk), dan CruzLacierda et al. (2008) (lebih dari 100 jenis produk) yang digunakan di tambak. Dari dokumen tersebut terlihat bahwa semakin tinggi sistem teknologi yang diaplikasikan, maka semakin banyak jenis produk kimia dan biologi yang digunakan. Selain itu, jumlah jenis produk kimia dan biologi yang digunakan pada tambak udang lebih banyak daripada tambak bandeng. Tampaknya, pada sistem teknologi yang lebih tinggi dan komoditas yang lebih rentan terhadap penyakit dan perubahan lingkungan menggunakan lebih banyak jenis produk kimia dan biologi dalam budidaya tambak. Keadaan alami tambak juga menentukan jumlah produk kimia dan biologi yang digunakan di tambak.

Produk kimia dan biologi digunakan dalam bidang akuakultur karena merupakan komponen yang esensial untuk: konstruksi tangki dan tambak; pengelolaan tanah dan air; peningkatan produktivitas alami; transportasi hidup organisme; formulasi pakan; manipulasi dan peningkatan reproduksi; merangsang pertumbuhan; pengelolaan kesehatan; serta pengolahan dan peningkatan nilai tambah produk akhir (Subasinghe et al., 2000). 
Tabel 1. Produk kimia dan biologi yang digunakan di tambak budidaya udang vaname (L. vannamei) di Kabupaten Pesawaran Provinsi Lampung

Table 1. Chemical and biological products used in the brackishwater ponds culture of whiteleg shrimp (L. vannamei) in Pesawaran Regency Lampung Province

\begin{tabular}{|c|c|c|}
\hline $\begin{array}{l}\text { Kelompok } \\
\text { Group }\end{array}$ & $\begin{array}{c}\text { Sub-kelompok } \\
\text { Sub-group }\end{array}$ & $\begin{array}{l}\text { Jenis produk } \\
\text { Type of product }\end{array}$ \\
\hline Disinfektan (2) & Klorin (1) & Kalsium hipoklorit (1) \\
\hline \multirow[t]{3}{*}{ Disinfectant } & Chlorine & Calcium hypochlorites \\
\hline & Kapur (1) & Kapur bakar (1) \\
\hline & Lime & Burned lime \\
\hline Pestisida (27) & Pestisida anorganik (1) & Tembaga sulfat (1) \\
\hline \multirow[t]{3}{*}{ Pesticide } & Inorganic perticide & Copper sulfate \\
\hline & Pestisida organik (27) & Biji teh (27) \\
\hline & Organic perticide & Teaseed \\
\hline Pupuk (21) & Pupuk anorganik (18) & Urea (3) \\
\hline \multirow[t]{4}{*}{ Fertilizer } & Inorganic fertilizer & $\operatorname{TSP}(10)$ \\
\hline & & NPK (9) \\
\hline & Pupuk organik (3) & Guano fosfat (3) \\
\hline & Organic fertilizer & Guano phosphate \\
\hline Perbaikan tanah dan air (29) & Kapur (26) & Kapur bakar (8) \\
\hline \multirow[t]{19}{*}{ Soil and water improvement } & Lime & Burned lime \\
\hline & & Kapur bangunan (5) \\
\hline & & Builders' lime \\
\hline & & Dolomit (21) \\
\hline & & Dolomite \\
\hline & & Kapur pertanian (9) \\
\hline & & Agricultural lime \\
\hline & Probiotik (26) & Fermentasi (5) \\
\hline & Probiotic & Akuasium Bacillus (2) \\
\hline & & $\mathrm{EM}-4(1)$ \\
\hline & & Bakteri (2) \\
\hline & & Starbio (1) \\
\hline & & Probiotik (2) \\
\hline & & Biobakteri (2) \\
\hline & & Sel Multi (1) \\
\hline & & Nitrosomonas (2) \\
\hline & & Nitrobacter (2) \\
\hline & & Probakter (1) \\
\hline & & Biomak (3) \\
\hline
\end{tabular}


Tabel 1. Lanjutan

Table 1. Continued

\begin{tabular}{|c|c|c|}
\hline $\begin{array}{l}\text { Kelompok } \\
\text { Group }\end{array}$ & $\begin{array}{c}\text { Sub-kelompok } \\
\text { Sub-group }\end{array}$ & $\begin{array}{l}\text { Jenis produk } \\
\text { Type of product }\end{array}$ \\
\hline & $\begin{array}{l}\text { Lainnya (8) } \\
\text { Others }\end{array}$ & $\begin{array}{l}\text { Episin (2) } \\
\text { Prowei (1) } \\
\text { Biou T (1) } \\
\text { Abusekam (1) } \\
\text { Argon (6) } \\
\text { Super PS (3) } \\
\text { Super NB (1) } \\
\text { Zeolit (5) } \\
\text { Biorin (1) } \\
\text { Roksin (1) } \\
\text { Pur (1) } \\
\text { Arang Batok (1) } \\
\text { Pond Plus (1) }\end{array}$ \\
\hline $\begin{array}{l}\text { Tambahan pakan (21) } \\
\text { Feed additives }\end{array}$ & $\begin{array}{l}\text { Vitamin (20) } \\
\text { Tanaman (1) } \\
\text { Plant } \\
\text { Lainnya (9) } \\
\text { Others }\end{array}$ & $\begin{array}{l}\text { Multivitamin (7) } \\
\text { Vitamin C (12) } \\
\text { Vitamin B Kompleks (3) } \\
\text { Bawang putih (1) } \\
\text { Garlic } \\
\text { Cisan (1) } \\
\text { Azomite (1) } \\
\text { Molsit (1) } \\
\text { Kalpros (1) } \\
\text { Boster Shrimp (1) } \\
\text { Biofit (2) } \\
\text { Vitaral Shrimp (3) } \\
\text { Biozyme (2) }\end{array}$ \\
\hline
\end{tabular}

Berdasarkan pendapat tersebut serta mempertimbangkan kriteria dari studi-studi sebelumnya mengenai penggunaan produk kimia dan biologi dalam bidang akuakultur (Primavera, 1993; Boyd \& Massaut, 1999; Phillips, 2000; Johnston \& Santillo, 2002; Gräslund et al., 2003; Lyle-Fritch et al., 2006; Alam, 2007; Cruz-Lacierda et al., 2008), maka jenis produk yang digunakan di tambak udang vaname Kabupaten Pesawaran dibagi atas 5 kelompok dengan masing-masing subkelompok seperti terlihat pada Tabel 1 dan Gambar 2. Kapur bakar (CaO) adalah satusatunya jenis produk yang termasuk pada dua kelompok yaitu disinfektan serta perbaikan tanah dan air.

\section{Disinfektan}

Bahan kimia rutin digunakan sebagai bahan pencegah atau sebagai disinfektan untuk mencegah atau mengontrol penyakit. Salah satu produk yang digunakan sebagai disinfektan di tambak budidaya udang vaname adalah klorin, walaupun hanya digunakan oleh 1 usaha budidaya tambak $(3,44 \%)$ di Kabupaten Pesawaran. Dosis kalsium hipoklorit (60\% klorin) yang digunakan adalah $0,85 \mathrm{mg} / \mathrm{L}$ untuk mematikan telur ikan yang masuk dalam tambak 


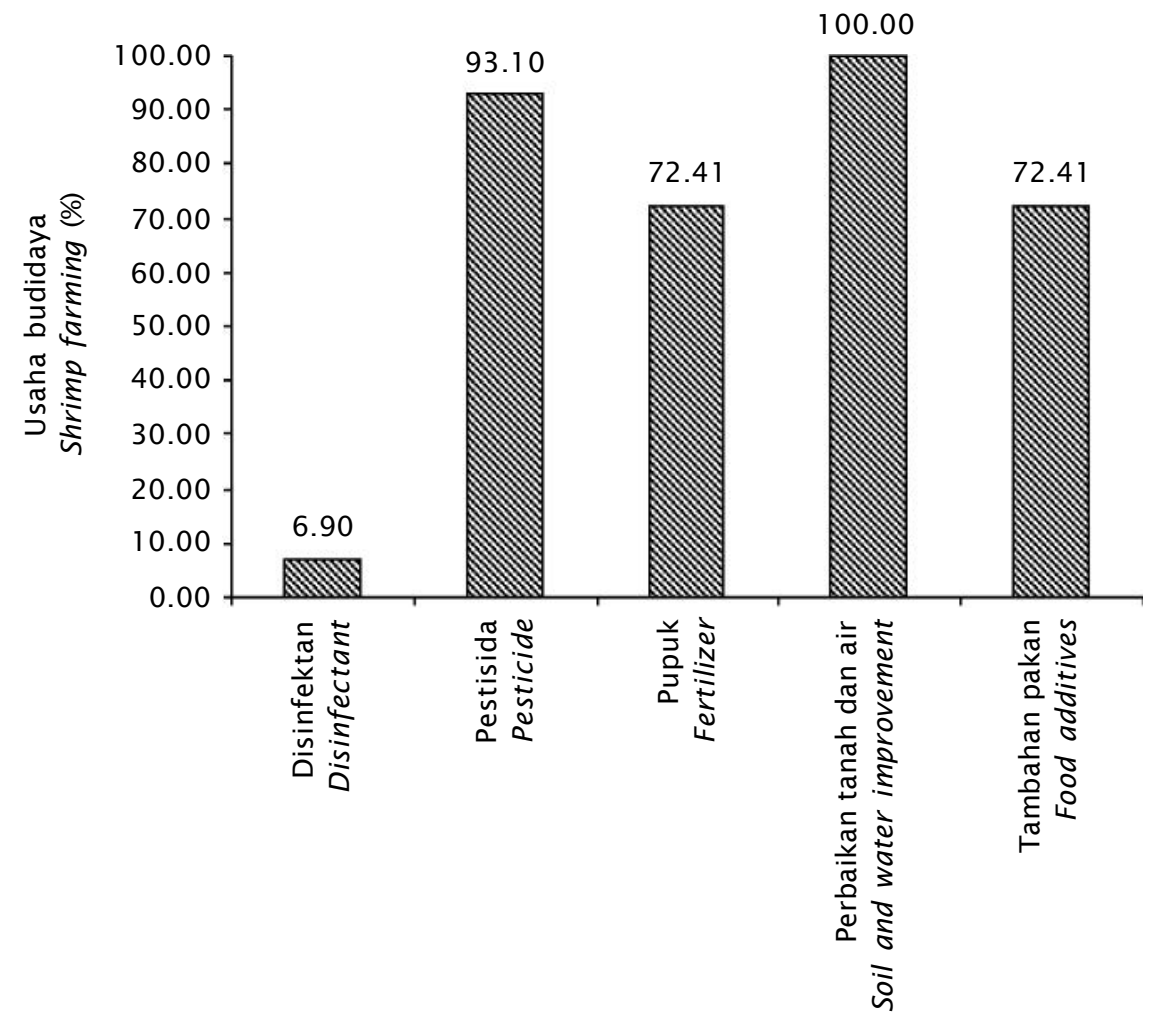

Gambar 2. Persentase usaha budidaya tambak untuk setiap kelompok produk yang digunakan di tambak budidaya udang vaname (L. vannamei) di Kabupaten Pesawaran Provinsi Lampung

Figure 2. Percentage of shrimp farming based on each product group used in the brackishwater ponds for whiteleg shrimp (L. vannamei) culture in Pesawaran Regency Lampung Province

yang berpotensi menjadi hama. Di Malaysia, kalsium hipoklorit dengan dosis $20-30 \mathrm{mg} / \mathrm{L}$ digunakan sebagai disinfektan dan dosis 0,08 $\mathrm{mg} / \mathrm{L}$ digunakan sebagai pencegah penyakit pada tambak di mana udang sedang dibudidayakan (Shariff et al., 2000). Menurut Cruz-Lacierda et al. (2008), klorinasi air yang masuk ke dalam tambak sudah menjadi standar prosedur operasional dalam budidaya udang. Awalnya, klorin digunakan secara tradisional sebagai pestisida dan perkembangan selanjutnya digunakan sebagai disinfektan pada air sumber untuk tambak (Shariff et al., 2000). Di Banglades, 25\% tambak udang semiintensif menggunakan klorin sebagai disinfektan pada air tambak (Phillips, 2000). Limsuwan (1993) juga melaporkan bahwa kalsium hipoklorit telah digunakan secara langsung pada dasar tambak oleh pem- budidaya di Thailand selama pengeringan untuk mencegah penyakit kepala kuning (yellowhead disease).

Produk lain yang digunakan oleh 1 usaha budidaya tambak $(3,44 \%)$ sebagai disinfektan adalah kapur bakar. Kapur bakar digunakan pada tambak yang tanah dasar tambaknya tidak dapat dikeringkan secara sempurna dan tanah dasar di sekitar pembuangan tengah. Kapur juga telah dipertimbangkan sebagai disinfektan di tambak Malaysia (Shariff et al., 2000), Cina (Yulin, 2000), dan Filipina (Cruz-Lacierda et al., 2008). Kapur bakar memiliki daya netralisasi tertinggi di antara kapur yang sering digunakan di tambak yaitu $179 \%$ sehingga reaksinya lebih cepat dan bila bereaksi dengan air akan meningkatkan suhu air sehingga dapat membunuh patogen. 


\section{Pestisida}

Hama dapat menurunkan produksi udang sehingga harus dihilangkan atau dikontrol dengan menggunakan pestisida anorganik dan atau organik sebelum penebaran. Ada 27 usaha budidaya tambak udang vaname $(93,10 \%)$ yang menggunakan pestisida dalam pemberantasan hama di tambak. Tambak yang tidak menggunakan pestisida dalam pemberantasan hama, melakukan pengeringan tambak secara sempurna untuk mematikan hama yang ada dalam tambak. Elevasi dasar tambak yang jauh di atas permukaan rata-rata air laut dan kemiringan dasar tambak yang cukup memadai menyebabkan lebih banyak tambak yang dapat dikeringkan secara sempurna.

Pestisida anorganik yaitu Blue copper hanya digunakan oleh 1 usaha budidaya tambak udang vaname $(3,44 \%)$ di Kabupaten Pesawaran dengan dosis aplikasi $1 \mathrm{mg} / \mathrm{L}$. Di tambak udang di India, Blue copper atau Copper sulfate $\left(\mathrm{CuSO}_{4} .5 \mathrm{H}_{2} \mathrm{O}\right)$ atau tembaga sulfat hanya digunakan oleh $1 \%$ tambak tradisional dan 2\% tambak semi-intensif dan tidak digunakan pada tambak intensif (Pathak et al., 2000). Tembaga sulfat digunakan dalam akuakultur untuk mengontrol eksternal parasit, penyakit karena bakteri dan juga sebagai fungisida dan herbisida (Shariff et al., 2000; Reddy et al., 2006; Widowati et al., 2008). Tembaga sulfat dengan dosis $0,25-1,0 \mathrm{mg} / \mathrm{L}$ digunakan untuk pemberantasan penyakit karena bakteri di tambak India (Pathak et al., 2000). Penggunaan yang terus-menerus dari tembaga sulfat pada tambak udang dapat berbahaya bagi udang serta memungkinkan terjadinya akumulasi tembaga dalam udang (Tonguthai, 2000; Reddy et al., 2006). Tembaga terakumulasi paling banyak pada hepatopankreas dari krustase (Liao \& Hsieh, 1990; Vijayram \& Geraldine, 1996). Dosis tembaga sulfat yang direkomendasikan oleh Boyd (1990) untuk krustase tergolong rendah yaitu 0,1-0,5 mg/L. Banyak jenis pestisida yang digunakan oleh pembudidaya tambak akan berdampak negatif terhadap budidaya udang karena meningkatkan risiko pada keamanan makanan, memiliki dampak negatif yang berhubungan dengan kesehatan manusia dan atau memiliki dampak negatif terhadap ekosistem (Gräslund et al., 2003).

Saponin adalah pestisida organik yang umum digunakan di tambak udang vaname yaitu 27 usaha tambak $(93,10 \%)$ di Kabupaten
Pesawaran. Saponin adalah produk sampingan dari proses pembuatan minyak dari biji tanaman teh (Camellia sinensis). Biji tanaman teh mengandung 10\%-15\% saponin yang efektif dalam mematikan hama ikan yang tidak diinginkan, namun tidak mematikan udang. Karena salinitas air tambak berkisar antara 15 sampai 35 ppt (Tabel 2), sehingga dosis saponin yang digunakan berkisar 15 sampai $20 \mathrm{mg} / \mathrm{L}$, di mana saponin dosis $15 \mathrm{mg} / \mathrm{L}$ digunakan pada salinitas lebih besar 20 ppt dan saponin dosis $20 \mathrm{mg} / \mathrm{L}$ digunakan pada salinitas kurang dari 20 ppt. Menurut Primavera (1993) dan Shariff et al. (2000), saponin tidak hanya mematikan hama ikan yang tidak diinginkan, tetapi juga dapat merangsang pergantian kulit dalam budidaya udang. Saponin dosis 2-3 mg/L selama 24 jam diaplikasikan untuk merangsang pergantian kulit pada udang windu dan saponin dosis 20$30 \mathrm{mg} / \mathrm{L}$ direkomendasikan untuk pembasmian penyakit bintik hitam (blackspot disease) pada udang (Shariff et al., 2000). Saponin dosis 5$25 \mathrm{mg} / \mathrm{L}$ telah digunakan dalam pembasmian infeksi protozoa di tambak (Baticados \& Paclibare, 1992). Saponin dapat juga berfungsi sebagai pupuk organik yang dapat merangsang pertumbuhan alga di tambak (Liao et al., 2000).

Supriyadi \& Rukyani (2000) telah melaporkan bahwa Brestan dan Thiodan adalah pestisida yang juga dipakai oleh pembudidaya tambak di Indonesia. Pada tambak tradisional di Indonesia, Brestan (nama generik Organotin) dan Thiodan (nama generik Endosulfan) digunakan untuk memberantas trisipan (Cerithidea cingulata) yang merupakan hama bagi ikan dan udang. Kedua jenis pestisida tersebut tidak digunakan oleh pembudidaya udang vaname di Kabupaten Pesawaran. Pemerintah sudah melarang penggunaan kedua pestisida tersebut di tambak, karena memiliki daya racun yang tinggi, sulit terurai, terakumulasi dalam tanah tambak dan memiliki potensial tinggi untuk terakumulasi dalam jaringan organisme. Perhatian terhadap kesehatan manusia dan lingkungan mengenai penggunaan produk kimia dan biologi dalam akuakultur telah tercermin dalam "FAO Code of Conduct for Responsible Fisheries" (FAO, 1995 dalam Subasinghe et al., 2000).

\section{Pupuk}

Pupuk ditambahkan ke tambak untuk meningkatkan kandungan nutrien, men- 
Tabel 2. Kualitas air di kawasan pertambakan budidaya udang vaname (L. vannamei) Kabupaten Pesawaran Provinsi Lampung

Table 2. Water quality condition in the brackishwater ponds for whiteleg shrimp (L. vannamei) culture in Pesawaran Regency Lampung Province

\begin{tabular}{lccc}
\hline \multicolumn{1}{c}{$\begin{array}{c}\text { Peubah } \\
\text { Variables }\end{array}$} & $\begin{array}{c}\text { Saluran } \\
\text { pemasukan } \\
\text { Inlet canal }\end{array}$ & $\begin{array}{c}\text { Saluran } \\
\text { pengeluaran } \\
\text { Outlet canal }\end{array}$ & $\begin{array}{c}\text { Tambak } \\
\text { Brackishwater } \\
\text { pond }\end{array}$ \\
\hline $\begin{array}{l}\text { Salinitas } \\
\text { Salinity (ppt) } \\
\text { Suhu }\end{array}$ & $15-35$ & $18-35$ & $22-35$ \\
Temperature $\left({ }^{\circ} \mathrm{C}\right)$ & $27.3-30.1$ & $27.2-30.9$ & $26.6-31.2$ \\
$\mathrm{pH}$ & $6.30-8.40$ & $7.60-8.42$ & $7.37-9.53$ \\
Oksigen terlarut & $4.6-8.2$ & $4.2-8.8$ & $3.5-8.4$ \\
Dissolved oxygen (mg/L) & $0.0039-1.4010$ & $0.0238-10.1570$ & $0.0019-2.3840$ \\
$\mathrm{NO}_{2}(\mathrm{mg} / \mathrm{L})$ & $0.0025-0.1255$ & $0.0113-0.7500$ & $0.0013-0.7500$ \\
$\mathrm{NO}_{3}(\mathrm{mg} / \mathrm{L})$ & $0.0098-0.0256$ & $0.0017-0.0500$ & $0.0033-0.0525$ \\
$\mathrm{NH}_{3}(\mathrm{mg} / \mathrm{L})$ & $0.0040-0.0200$ & $<0.0001-0.2420$ & $<0.0001-0.2150$ \\
$\mathrm{PO}_{4}(\mathrm{mg} / \mathrm{L})$ & &
\end{tabular}

stimulasi pertumbuhan plankton, dan meningkatkan suplai pakan pada budidaya udang. Pada budidaya udang, pupuk diaplikasikan untuk menstabilkan populasi plankton (Cruz-Lacierda et al., 2008). Dalam studi ini, 20 usaha budidaya tambak $(68,97 \%)$ mengaplikasikan pupuk anorganik dan 3 usaha budidaya tambak (10,34\%) mengaplikasikan pupuk organik. Pupuk dan kapur adalah produk kimia yang paling banyak digunakan di tambak Asia (Phillips, 2000). Di Filipina, banyak tambak menggunakan pupuk anorganik dan organik untuk menghasilkan dan mempertahankan produktivitas alami (Cruz-Lacierda et al., 2008).

Pupuk anorganik yang digunakan di tambak udang vaname di Kabupaten Pesawaran adalah Urea, TSP, dan NPK. Pupuk anorganik ini, tidak hanya digunakan sebagai pupuk awal tetapi juga sebagai pupuk susulan. Pupuk Urea (460-0) digunakan dengan dosis 56 sampai 111 $\mathrm{kg} / \mathrm{ha}$ sebagai pupuk awal oleh 3 usaha budidaya tambak (10,34\%). Total Urea yang diberikan sebagai pupuk susulan adalah 56 $\mathrm{kg} / \mathrm{ha}$ dan hanya diaplikasikan oleh 1 usaha budidaya tambak (3,44\%). Pupuk TSP (0-45-0) digunakan dengan dosis 20 sampai $180 \mathrm{~kg} /$ ha sebagai pupuk awal yang diaplikasikan oleh 7 usaha budidaya tambak (24,14\%). Dosis total TSP sebagai pupuk susulan adalah 50 sampai $111 \mathrm{~kg} / \mathrm{ha}$ yang diaplikasikan oleh 3 usaha budidaya tambak (10,34\%). Pupuk NPK (14-1414) yang tergolong pupuk lengkap karena mengandung unsur hara makro yang penting dalam budidaya tambak digunakan dengan dosis 17 sampai $333 \mathrm{~kg} /$ ha sebagai pupuk awal yang diaplikasikan oleh 5 usaha budidaya tambak (17,24\%). Sebagai pupuk susulan, total dosis NPK yang digunakan 50 sampai $84 \mathrm{~kg} /$ ha yang diaplikasikan oleh 4 usaha budidaya tambak (13,79\%). Pupuk susulan umumnya diaplikasikan pada saat pembacaan piring secchi lebih dari $50 \mathrm{~cm}$. Dalam budidaya udang vaname di Meksiko, pupuk anorganik yang digunakan adalah pupuk-P, pupuk N-P-Si dan pupuk Urea (Lyle-Fritch et al., 2006).

Satu-satunya pupuk organik yang digunakan dalam budidaya udang vaname di Kabupaten Pesawaran adalah guano fosfat. Pupuk guano fosfat adalah pupuk organik dari kotoran burung yang mengandung $\mathrm{P}_{2} \mathrm{O}_{5}$ sekitar $20 \%$. Pupuk guano fosfat hanya diaplikasikan oleh 3 usaha budidaya tambak (10,34\%) dengan menggunakan dosis 111 sampai $385 \mathrm{~kg} / \mathrm{ha}$. Kurangnya usaha budidaya tambak udang vaname mengaplikasikan guano fosfat, mungkin terkait dengan kandungan bahan organik dari pupuk tersebut. Selain itu, kandungan bahan organik pada budidaya udang intensif dan super-intensif dapat bertambah sebagai akibat sisa pakan dan 
kotoran udang itu sendiri. Telah dilaporkan sebelumnya oleh Mustafa et al. (2008) bahwa bahan organik diperlukan dalam budidaya udang vaname sampai pada kandungan 3,31\% dan kandungan yang lebih tinggi akan berdampak pada penurunan produksi udang vaname. Kandungan bahan organik yang tinggi dapat menyebabkan peningkatan populasi bakteri, $\mathrm{CO}_{2}, \mathrm{H}_{2} \mathrm{~S}$, dan $\mathrm{CH}_{4}$ yang dapat membahayakan kehidupan dan menghambat pertumbuhan udang vaname. Dikatakan oleh Paquotte et al. (1998) bahwa udang vaname berada dalam kondisi pemeliharaan yang sangat baik apabila udang vaname tidak kontak dengan bahan organik termasuk limbah organik. Penggunaan pupuk pada budidaya tambak diharapkan tidak berdampak negatif pada lingkungan dan belum ada masalah lingkungan yang didapatkan di Asia sebagai akibat penggunaan pupuk (Phillips, 2000). Sebelumnya, Boyd \& Massaut (1999) menyatakan bahwa penggunaan pupuk anorganik dalam akuakultur tidak berdampak negatif terhadap keamanan makanan yang diproduksi di tambak.

\section{Perbaikan Tanah dan Air}

Pada kawasan intertidal di Kabupaten Pesawaran, tambak dibangun pada tanah sulfat masam dan tanah gambut atau tanah sulfat masam yang berasosiasi dengan tanah gambut. Tanah tersebut tergolong tanah bermasalah sebab tingkat kemasaman dan kandungan unsur toksik tergolong tinggi dan sebaliknya kandungan unsur hara makronya rendah. Khusus pada tanah gambut juga memiliki kandungan bahan organik yang tinggi. Sebagai akibatnya, penggunaan kapur menjadi penting sebagai bahan remediasi untuk memperbaiki kualitas tanah berupa penurunan kemasaman dan kandungan unsur toksik serta peningkatan ketersediaan unsur hara makro (Mustafa \& Sammut, 2007).

Ada 4 jenis kapur yang digunakan sebagai kapur awal dan 3 jenis kapur yang digunakan sebagai kapur susulan dalam budidaya udang vaname di tambak Kabupaten Pesawaran. Kapur awal diaplikasikan pada saat persiapan tambak dengan dosis yang lebih tinggi dibandingkan dengan kapur susulan yang diaplikasikan pada saat budidaya udang vaname sedang berjalan (Tabel 3). Kapur bakar $(\mathrm{CaO})$, selain digunakan oleh usaha budidaya udang sebagai disinfektan, seperti telah dijelaskan sebelumnya, juga digunakan untuk perbaikan tanah dan air yang diaplikasikan sebagai kapur awal. Untuk tambak yang tergolong tanah bermasalah, kapur yang digunakan adalah kapur bangunan $\left(\mathrm{CaOH}_{2}\right)$ yang dapat meningkatkan $\mathrm{pH}$ tanah lebih besar daripada menggunakan dolomit $\left(\mathrm{CaMg}\left(\mathrm{CO}_{3}\right)_{2}\right)$ dan kapur pertanian atau kaptan $\left(\mathrm{CaCO}_{3}\right)$ pada dosis yang sama. Di Filipina, kapur bangunan digunakan pada tambak yang baru beroperasi dan tambak yang memiliki $\mathrm{pH}<5,0$ (CruzLacierda et al., 2008). Dosis kapur bangunan yang digunakan juga lebih tinggi digunakan dibandingkan dengan jenis kapur lainnya

Tabel 3. Penggunaan kapur sebagai kapur awal di tambak udang vaname (L. vannamei) di Kabupaten Pesawaran Provinsi Lampung

Table 3. Initial liming practices in the brackishwater ponds for whiteleg shrimp (L. vannamei) culture in Pesawaran Regency Lampung Province

\begin{tabular}{lcc}
\hline \multicolumn{1}{c}{$\begin{array}{c}\text { Jenis kapur } \\
\text { Types of lime }\end{array}$} & $\begin{array}{c}\text { Jumlah usaha budidaya } \\
\text { Number of farming }\end{array}$ & $\begin{array}{c}\text { Dosis } \\
\text { Dosage }(\mathbf{k g} / \mathbf{h a})\end{array}$ \\
\hline $\begin{array}{l}\text { Kapur bakar } \\
\text { Burned lime }\end{array}$ & 9 & - \\
$\begin{array}{l}\text { Kapur bangunan } \\
\text { Builders' lime } \\
\text { Dolomit } \\
\begin{array}{l}\text { Dolomite } \\
\text { Kapur pertanian } \\
\text { Agricultural lime }\end{array}\end{array}$ & 3 & $6,062(667-15,000)$ \\
\hline
\end{tabular}


Tabel 4. Penggunaan kapur sebagai kapur susulan di tambak udang vaname (L. vannamei) di Kabupaten Pesawaran Provinsi Lampung

Table 4. Liming continuation practices in the brackishwater pond for whiteleg shrimp (L. vannamei) culture of Pesawaran Regency Lampung Province

\begin{tabular}{lcc}
\hline \multicolumn{1}{c}{$\begin{array}{c}\text { Jenis kapur } \\
\text { Kind of lime }\end{array}$} & $\begin{array}{c}\text { Jumlah usaha budidaya } \\
\text { Number of farming }\end{array}$ & $\begin{array}{c}\text { Dosis (kg/ha/siklus) } \\
\text { Dosage }(\mathbf{k g} / \mathbf{h a} / \mathbf{c y c l e})\end{array}$ \\
\hline $\begin{array}{l}\text { Kapur bangunan } \\
\text { Builders' lime } \\
\begin{array}{l}\text { Dolomit } \\
\text { Dolomite }\end{array}\end{array}$ & 2 & $1,623(456-3,200)$ \\
$\begin{array}{l}\text { Kapur pertanian } \\
\text { Agricultural lime }\end{array}$ & 14 & $1,888(48-6,667)$ \\
\hline
\end{tabular}

(Tabel 3). Dosis kapur yang diaplikasikan hanya didasarkan pada $\mathrm{pH}$ tanah tambak. Penggunaan dosis kapur yang tinggi pada tambak yang tergolong tanah bermasalah tersebut bukan saja karena memiliki $\mathrm{pH}$ yang lebih rendah, tetapi juga sebagai akibat dari pengapuran yang tidak hanya dilakukan pada tanah dasar tambak saja, tetapi juga pada tanah pematang tambak. Pengapuran pada pematang tambak dimaksudkan untuk menetralisir kemasaman tanah yang biasanya tinggi karena terjadinya proses oksidasi pada tanah pematang yang menyebabkan terlarutnya berbagai senyawa toksik dan terbawa masuk dalam tambak bila terjadi hujan.

Penggunaan dolomit dan kaptan, selain untuk meningkatkan $\mathrm{pH}$ tanah atau menetralisir kemasaman yang masih ada, juga dimaksudkan untuk menambah Ca serta Mg (dari dolomit) pada tanah. Selain itu, daya netralisasi dari dolomit dan kaptan yang lebih rendah dari kapur bangunan, maka kedua jenis kapur ini digunakan pada tambak yang tergolong bukan tanah bermasalah.

Pengapuran susulan hanya dilakukan oleh 20 usaha budidaya tambak udang vaname $(68,97 \%)$ di Kabupaten Pesawaran. Pengapuran susulan dilakukan pada saat alkalinitas air kurang dari $80 \mathrm{mg} / \mathrm{L}$ atau setelah terjadi hujan terutama pada tambak yang tanahnya tergolong tanah bermasalah. Pengapuran susulan ini tidak hanya langsung diaplikasikan pada air tambak, tetapi juga pada tanah pematang. Pada tambak yang tergolong tanah bermasalah, tetapi pematangnya dikonstruksi dengan beton atau dilapisi plastik, maka pengapuran susulan hanya dilakukan terhadap air tambak saja. Oleh karena itu, dosis dan frekuensi kapur susulan yang digunakan sangat beragam. Dosis yang tertera pada Tabel 4 adalah merupakan total kapur yang digunakan selama satu siklus pemeliharaan. Dolomit adalah jenis kapur yang banyak digunakan sebagai kapur susulan, selain karena dapat meningkatkan $\mathrm{pH}$ air tidak terlalu drastis juga dapat meningkatkan daya sangga air juga sebagai sumber $\mathrm{Ca}$ dan $\mathrm{Mg}$ yang sangat diperlukan udang vaname dalam pembentukan kulitnya. Seperti halnya penggunaan pupuk, maka penggunaan kapur dalam tambak belum pernah dilaporkan berdampak negatif terhadap lingkungan (Boyd \& Massaut, 1999; Phillips, 2000). Namun demikian, penggunaan kapur bakar sebagai kapur susulan dengan dosis yang sangat tinggi telah dilaporkan dapat menyebabkan kematian udang windu di tambak Kabupaten Pinrang Provinsi Sulawesi Selatan (Mustafa \& Ratnawati, 2007).

Produk kimia lain yang digunakan usaha budidaya tambak udang vaname untuk perbaikan kualitas tanah dan air adalah zeolit yang digunakan oleh 5 usaha budidaya tambak udang vaname $(17,24 \%)$ (Tabel 1). Dosis zeolit yang digunakan berkisar antara 800 dan 2.500 $\mathrm{kg} / \mathrm{ha} /$ siklus untuk memperbaiki kualitas tanah dan air dan dosis tersebut adalah akumulasi dari setiap pemberian selama satu siklus pemeliharaan. Frekuensi pemberian zeolit sangat ditentukan oleh kondisi kualitas tanah dan air. Zeolit digunakan di dasar tambak untuk menghilangkan $\mathrm{H}_{2} \mathrm{~S}, \mathrm{CO}_{2}$, dan $\mathrm{NH}_{3}$ sebab memiliki kemampuan yang kuat untuk 
menyerap molekul sehingga dikatakan juga dapat membersihkan dasar tambak yang berdampak pada peningkatan kualitas dasar tambak (Shariff et al., 2000; Tonguthai, 2000). Namun demikian, kemampuan zeolit tersebut menjadi semakin berkurang dalam menyerap $\mathrm{NH}_{3}$ seiring dengan peningkatan kesadahan atau salinitas air. Di India, zeolit diaplikasikan bersama dengan kapur untuk mengaktifkan kembali tanah dalam menstabilkan pertumbuhan alga dan menyerap material penempel (Pathak et al., 2000).

Probiotik adalah bakteri yang bermanfaat di mana perkembangan patogen dihambat dengan memproduksi senyawa penghambat atau mencegah kolonisasi patogen dalam inang (Ringgo, 2002). Probiotik ini digunakan oleh 18 usaha budidaya tambak udang vaname $(62,10 \%)$ di Kabupaten Pesawaran (Tabel 1). Dosis dan frekuensi aplikasi probiotik umumnya disesuaikan dengan rekomendasi dari setiap produk yang tercantum pada kemasannya. Berbagai macam probiotik komersial dan komponen bahannya yang digunakan di tambak udang vaname Kabupaten Pesawaran dapat dilihat pada Tabel 1. Di Meksiko, probiotik hanya diaplikasikan pada budidaya udang vaname sistem semiintensif pada saat ada tanda-tanda klinis serangan penyakit (Lyle-Fritch et al., 2006).

Sejak tahun 2002, budidaya udang vaname di Indonesia termasuk di Provinsi Lampung mulai terserang oleh penyakit. Pada saat studi dilakukan yaitu pada tahun 2007, seluruh tambak udang vaname di Kabupaten Pesawaran pernah terserang oleh penyakit (Tabel 5). Ada tiga jenis penyakit yang teridentifikasi menyerang udang vaname adalah IMNV (Infectious Myo Necrotic Virus), WSSV (White Spot Syndrome Virus), dan TSV (Taura Syndrome Virus) yang semuanya diakibatkan oleh virus. Virus yang mematikan udang vaname di tambak Indonesia adalah IMNV, WSSV, TSV, dan noda virus, sedangkan yang mengkerdilkan udang vaname adalah IHHNV (Infectious Hypodermal and Hematopoietic Necrosis Virus). Virus penyebab penyakit ini sama dengan yang menyerang tambak udang vaname di Meksiko, tetapi tambak udang vaname di Meksiko juga diserang penyakit akibat vibriosis, bakteri, dan parasit (Lyle-Fritch et al., 2006). Dari Tabel 5 terlihat bahwa ada 10 usaha budidaya tambak (34,48\%) yang terserang penyakit, namun tidak dapat teridentifikasi jenis penyakitnya. Pathak et al.
(2000) dan Lyle-Fritch et al. (2006) yang melakukan survai penggunaan produk kimia dan biologi juga menginformasikan bahwa banyak pengelola tambak udang yang tidak mampu mengidentifikasi penyakit dan juga tidak mampu memberikan informasi yang akurat tentang tanda-tanda klinik serangan penyakit. $\mathrm{Hal}$ ini tentunya dapat mengakibatkan terjadinya kesulitan dalam mengambil tindakan yang tepat untuk mencegah lebih meluasnya serangan penyakit tersebut. Hal yang umum dilakukan usaha budidaya tambak saat terjadinya penyakit terutama penyakit yang tidak dapat diidentifikasi penyebabnya adalah dengan meningkatkan volume pergantian air, melakukan pengapuran susulan serta mengaplikasikan probiotik.

Di tambak udang vaname di Meksiko, aplikasi antibiotik dilakukan pada saat dijumpai tanda-tanda klinis serangan penyakit (LyleFritch et al., 2006). Di tambak udang vaname Kabupaten Pesawaran tidak dijumpai adanya aplikasi antibiotik selama budidaya berlangsung, walaupun terjadi serangan penyakit. Hal ini terkait dengan upaya keras pemerintah untuk menghapuskan secara total penggunaan antibiotik dalam pengembangan budidaya perikanan di berbagai daerah. Pada Pasal 86 Ayat 4 UU No. 31 Tahun 2004 tentang perikanan telah disebutkan sanksi dalam penggunaan tetracycline, oxytetracycline, nitrofuran, chloramphenicol, leucomalachite green, dan malachite green dalam budidaya ikan. Seperti diketahui bersama bahwa udang beku Indonesia ditolak oleh Uni Eropa dengan alasan terdeteksinya residu antibiotika yang terjadi sejak tahun 2000 hingga 2007 (Murdjani et al., 2007). Sebelumnya telah dilaporkan oleh Supriyadi \& Rukyani (2000) bahwa antibiotik seperti: oxytetracycline, chloramphenicol, neomycin, streptomycin, erythromycin, prefuran, dan enrofloxacin telah digunakan dalam bidang akuakultur di Indonesia.

\section{Tambahan Pakan}

Seluruh tambak udang vaname di Kabupaten Pesawaran menggunakan pakan komersial, karena sistem budidaya yang diaplikasikan adalah intensif dan superintensif di mana pakan komersial menjadi kebutuhan mutlak. Namun demikian, 22 usaha budidaya tambak $(75,86 \%)$ menambahkan tambahan pakan pada pakan komersial yang dimaksudkan untuk melengkapi kebutuhan 
Tabel 5. Daftar penyakit yang didapatkan pada tambak budidaya udang vaname (L. vannamei) di Kabupaten Pesawaran Provinsi Lampung

Table 5. List of diseases found in the brackishwater ponds culture of whiteleg shrimp (L. vannamei) in Pesawaran Regency Lampung Province

\begin{tabular}{|c|c|c|c|c|}
\hline \multirow{2}{*}{$\begin{array}{l}\text { Usaha budidaya } \\
\text { Farming }\end{array}$} & \multicolumn{4}{|c|}{ Penyakit (Disease) } \\
\hline & IMNV & WSSV & TSV & Tidak diket ahui (Unknown) \\
\hline 1 & & & & $\checkmark$ \\
\hline 2 & $\checkmark$ & & & \\
\hline 3 & $\checkmark$ & & & \\
\hline 4 & & & & $\checkmark$ \\
\hline 5 & $\checkmark$ & & & \\
\hline 6 & & & & $\checkmark$ \\
\hline 7 & $\checkmark$ & & & \\
\hline 8 & $\checkmark$ & & & \\
\hline 9 & $\checkmark$ & & & \\
\hline 10 & $\checkmark$ & & & \\
\hline 11 & $\checkmark$ & & & \\
\hline 12 & $\checkmark$ & & & \\
\hline 13 & $\checkmark$ & & & \\
\hline 14 & & $\checkmark$ & & \\
\hline 15 & $\checkmark$ & & & \\
\hline 16 & $\checkmark$ & & & \\
\hline 17 & & & & $\checkmark$ \\
\hline 18 & & & & $\checkmark$ \\
\hline 19 & & & & $\checkmark$ \\
\hline 20 & $\checkmark$ & & & \\
\hline 21 & & & & $\checkmark$ \\
\hline 22 & & & & $\checkmark$ \\
\hline 23 & $\checkmark$ & & & \\
\hline 24 & $\checkmark$ & & & \\
\hline 25 & & & & $\checkmark$ \\
\hline 26 & $\checkmark$ & & & \\
\hline 27 & & & $\checkmark$ & \\
\hline 28 & & & & $\checkmark$ \\
\hline 29 & $\checkmark$ & & & \\
\hline Total & 17 & 1 & 1 & 10 \\
\hline
\end{tabular}

IMNV : Infectious Myo Necrotic Virus

WSSV : White Spot Syndrome Virus

TSV : Taura Syndrome Virus 
antibiotik alami bagi hewan dan ikan, sebab mengandung allicin yang mampu secara efektif membunuh kuman atau bakteri dan juga mengandung sativine yang berfungsi mempercepat pertumbuhan sel dan jaringan (Anonim, 2009).

Rasio konversi pakan antara sistem budidaya udang intensif berbeda tidak nyata dengan sistem super-intensif di tambak Kabupaten Pesawaran (Tabel 6). FAO (2009) melaporkan bahwa rasio konversi pakan pada budidaya udang vaname sistem intensif dan super-intensif masing-masing 1,4-1,8 dan 1,52,6 . Udang vaname sangat efisien dalam pemanfaatan produktivitas alami dari tambak pada kondisi budidaya intensif. Biaya pakan udang vaname secara umum lebih murah daripada udang laut yang lebih karnivor seperti udang windu, sebagai akibat kebutuhannya yang lebih rendah untuk protein (18\%-35\% dibandingkan dengan 36\%-42\%), terutama di mana sistem bakteri flok digunakan (FAO, 2009).

Produktivitas tambak untuk udang vaname pada sistem super-intensif lebih tinggi dan berbeda nyata dengan tambak udang intensif (Tabel 6). Hal ini dapat dimengerti sebab padat penebaran yang diaplikasikan pada tambak udang super-intensif lebih tinggi daripada tambak udang intensif, sehingga berdampak pada produksi yang juga lebih tinggi. Ini dapat juga dijadikan petunjuk bahwa tidak terjadi perbedaan antara bobot dan sintasan udang vaname pada sistem budidaya yang berbeda itu. Dengan kriteria yang sama mengenai padat penebaran dengan studi ini, Lyle-Fritch et al. (2006) mendapatkan produksi udang vaname pada sistem intensif dan super-intensif masingmasing 12.000 dan $46.500 \mathrm{~kg} / \mathrm{ha} / \mathrm{siklus} \mathrm{di}$ Meksiko. Produksi udang vaname sistem intensif berkisar 7.000 sampai dengan 20.000 $\mathrm{kg} / \mathrm{ha} /$ siklus (FAO, 2009).

Menurut Teichert-Coddington et al. (1999), pada budidaya udang intensif akan menghasilkan beban limbah sebesar 12,6-21,0 $\mathrm{kg} \mathrm{N}$ dan 1,8-3,6 kg $\mathrm{P}$ setiap ton produksi udang. Berdasarkan pendapat tersebut serta produksi dan luas tambak yang digunakan untuk produksi udang vaname di Kabupaten Pesawaran, maka menghasilkan beban limbah 21.349-35.582 kg N dan 3.050-6.100 kg P pada setiap siklus budidaya. Oleh karena seluruh tambak di lokasi studi mengambil air laut secara langsung dan membuang di dalam Teluk Lampung maka sebagai akibatnya, 14 usaha budidaya tambak $(48,28 \%)$ merasakan adanya pencemaran yang berasal dari tambak lainnya (Tabel 7). Sumber pencemaran lainnya adalah dari pertanian yang dialami oleh 1 usaha budidaya tambak $(3,44 \%)$, sedangkan kegiatan pemukiman, perkotaan, pertambangan, industri, dan pelayaran belum menyebabkan pencemaran pada budidaya udang vaname di Kabupaten Pesawaran. Sumber pencemaran yang berasal dari tambak yang dapat mencemari tambak lainnya diperkuat dengan data

Tabel 7. Sumber air pencemaran tambak udang vaname (L. vannamei) di Kabupaten Pesawaran Provinsi Lampung

Table 7. Sources of water pollution of whiteleg shrimp (L. vannamei) brackishwater ponds in Pesawaran Regency Lampung Province

\begin{tabular}{lcc}
\hline \multicolumn{1}{c}{$\begin{array}{c}\text { Sumber } \\
\text { Source }\end{array}$} & $\begin{array}{c}\text { Jumlah usaha budidaya } \\
\text { Number of }\end{array}$ & $\begin{array}{c}\text { Persentase } \\
\text { Percentage }\end{array}$ \\
\hline Pertanian (Agricultural) & 1 & 3.44 \\
Pemukiman (Settlement) & 0 & 0 \\
Perkotaan (Urban) & 0 & 0 \\
Pertambangan (Mining) & 0 & 0 \\
Tambak lainnya (Other shrimp farming) & 14 & 48.28 \\
Industri (Industry) & 0 & 0 \\
Pelayaran (Shipping) & 0 & 0 \\
Tidak ada (None) & 14 & 48.28 \\
\hline \multicolumn{1}{c}{ Total } & 29 & 100.00 \\
\hline
\end{tabular}


kualitas air seperti yang terlihat pada Tabel 2. Dari Tabel 2 terlihat adanya kecenderungan lebih tingginya kandungan senyawa-senyawa yang bersifat toksik maupun yang bersifat sebagai nutrien pada saluran pengeluaran dibandingkan dengan saluran pemasukan dan dalam tambak itu sendiri. Menurut Brodie (1995), limbah yang berasal dari budidaya perikanan dengan sumber yang tergolong sedang jumlahnya adalah nutrien dan bahanbahan penyebab turunnya oksigen terlarut, sedangkan limbah dengan sumber yang tergolong kecil jumlahnya adalah sedimen, zat kimia toksik, pestisida, dan organisme eksotik.

\section{KESIMPULAN DAN SARAN}

Dari studi yang dilakukan di tambak udang vaname (Litopenaeus vannamei) di Kabupaten Pesawaran Provinsi Lampung dapat disimpulkan bahwa ada 48 jenis produk kimia dan biologi yang digunakan di tambak dan dapat dikelompokkan atas 5 kelompok yaitu: disinfektan, pestisida, pupuk, perbaikan tanah, dan air serta tambahan pakan. Pestisida organik dan kapur adalah sub-kelompok produk yang banyak digunakan dan sebaliknya pestisida anorganik adalah sub-kelompok produk yang paling sedikit digunakan di tambak udang vaname. Produk kimia dan biologi yang bersifat sangat beracun, sulit terurai, dapat terakumulasi dalam tubuh organisme dan berbahaya bagi keselamatan makanan ternyata tidak digunakan dalam budidaya tambak udang vaname. Dengan berdasar pada produksi dan luasan tambak udang vaname intensif dan super-intensif maka dihasilkan beban limbah sebesar 21.349$35.582 \mathrm{~kg} \mathrm{~N}$ dan 3.050-6.100 kg P pada setiap siklus budidaya yang memiliki potensi sebagai pencemar untuk budidaya udang vaname itu sendiri di Kabupaten Pesawaran. Oleh karena itu, produk kimia dan biologi yang digunakan di tambak sebaiknya dapat digunakan secara aman, efektif, dan ekonomis.

\section{UCAPAN TERIMA KASIH}

Diucapkan terima kasih kepada Proyek ACIAR FIS/2002/076 Land Capability Assessment and Classification for Sustainable Pondbased, Aquaculture Systems atas biaya studi ini.

\section{DAFTAR ACUAN}

Alam, S.M.N. 2007. Biological and chemical products use in extensive shrimp farming in Southwest Bangladesh. Journal of Fisheries and Aquatic Science, 2(1): 56-62.

APHA (American Public Health Association). 2005. Standard methods for examination of water and wastewater. APHA-AWWA-WEF, Washington, DC, 1,185 pp.

Boonyaratpalin, M. 2000. The use of chemicals in aquafeed. In: Arthur, J.R., C.R. LavillaPitogo and R.P. Subasinghe (Eds.), Use of Chemicals in Aquaculture in Asia. Southeast Asian Fisheries Development Center Aquaculture Department, Tigbauan, Iloilo, Philippines,p. 35-54.

Boyd, C.E. 1990. Water Quality in Ponds for Aquaculture. Alabama Agricultural Experiment Station, Auburn University, Alabama, $482 \mathrm{pp}$.

Boyd, C.E. \& Massaut, L. 1999. Risks associated with the use of chemicals in pond aquaculture. Aquacultural Engineering, 20(2): 113-132.

Brodie, J. 1995. Water quality and pollution control. In: Hotta, K. and I. Dutton (Eds.), Coastal Management in the Asia Pacific: Issue and Approaches. Japan International Marine Science and Technology Federation, Tokyo, p. 39-56.

Catacutan, M.R. \& Lavilla-Pitogo, C.R. 1994. L-ascorbyly-2-phosphate Mg as a source of vitamin C for juvenile Penaeus monodon. Israeli Journal of Aquaculture Bamidgeh, 46: 40-47.

Coakes, S.J., Steed, L., \& J. Price. 2008. SPSS: Analysis without Anguish: Version 15.0 for Windows. John Wiley \& Sons Australia, Ltd., Milton, Qld., 270 pp.

Cruz-Lacierda, E.R., de la Peña, L.D., \& LumanlanMayo, S.C. 2000. The use of chemicals in aquaculture in the Philippines. In: Arthur, J.R., C.R. Lavilla-Pitogo, and R.P. Subasinghe (Eds.), Use of Chemicals in Aquaculture in Asia. Southeast Asian Fisheries Development Center Aquaculture Department, Tigbauan, Iloilo, Philippines, p. 155-184.

Cruz-Lacierda, E.R., Corre, V.L.Jr., Yamamoto, A., Koyama, J., and Matsuoka, T. 2008. Current status on the use of chemicals and biological products and health management practices in aquaculture farms in the Philippines. Mem. Fac. Fish. Kagoshima Univ., 57: 37-45.

FAO (Food and Agriculture Organisation). 2009. Production methods for the whiteleg shrimp. http://www.thefishsite.com/ 
articles/713/production-methods-for-thewhiteleg-shrimp. Diakses 08/07/2009.

Gräslund, S. \& Bengstsson, B.-E. 2001 . Chemicals and biological products used in southeast Asian shrimp farming, and their potential impact on the environment: a review. Science of the Total Environment, 280(1-3): 93-131.

Gräslund, S., Holmström, K., \& Wahlström, A. 2003. A field survey of chemicals and biological products used in shrimp farming. Marine Pollution Bulletin, 46(1): 81-90.

Hamre, K., Christiansen, R., Waagbø, R., Maage, A., Torstensen, Lygren, B., Lie, Ø., Wathne, E., \& Albrektsen, S. 2004. Antioxidant vitamins, minerals and lipid levels in diets for Atlantic salmon (Salmo salar, L.): effects on growth performance and fillet quality. Aquaculture Nutrition, 10: 113-123.

Johnston, P. \& Santillo, D. 2002. Chemical Usage in Aquaculture: Implications for Residues in Market Products. Greenpeace Research Laboratories, Department of Biological Sciences, University of Exeter, UK, 16 pp.

Liao, I. \& Hsieh, C. 1990. Toxicity of three heavy metals to Macrobrachium rosenbergii. In: Hirano, R. and I. Hanyu (Eds.), Proceedings of the Second Asian Fisheries Forum. Asian Fisheries Society, Manila, Philippines, p. 923-926.

Liao, I.C., Guo, J.-J., \& Su, M.-S. 2000. The use of chemicals in aquaculture in Taiwan, Province of China. In: Arthur, J.R., C.R. LavillaPitogo and R.P. Subasinghe (Eds.), Use of Chemicals in Aquaculture in Asia. Southeast Asian Fisheries Development Center Aquaculture Department, Tigbauan, Iloilo, Philippines, p. 193-205.

Limsuwan, C. 1993. Shrimp diseases and health management in South East Asia. In: Subasinghe, R.P and M. Shariff (Eds.), Diseases in Aquaculture: the Current Issues. Malaysian Fisheries Society, Serdang, Selangor, p. 71-96.

Lyle-Fritch, L.P., Romero-Beltrán, E., \& PáezOsuna, F. 2006. A survey on use of the chemical and biological products for shrimp farming in Sinaloa (NW Mexico). Aquacultural Engineering, 35(2): 135-146.

Murdjani, M., Arifin, Z., Adiwidjaya, D., Komarudin, U., Nur, A., Susanto, A., Taslihan, A., Ariawan, K., Mardjono, M., Sutikno, E., Supito, \& Latief, M.S. 2007. Penerapan Best
Management Practices (BMP) pada Budidaya Udang Windu (Penaeus monodon Fabricius) Intensif. Balai Besar Pengembangan Budidaya Air Payau, Jepara, $68 \mathrm{hlm}$.

Mustafa, A. \& Sammut, J. 2007. Effect of different remediation techniques and dosages of phosphorus fertilizer on soil quality and klekap production in acid sulfate soil-affected aquaculture ponds. Indonesian Aquaculture Journal, 2(2): 141-157.

Mustafa, A. \& Ratnawati, E. 2007. Faktor-faktor dominan yang mempengaruhi produktivitas tambak di Kabupaten Pinrang, Sulawesi Selatan. Jurnal Riset Akuakultur, 2(1): 117 133.

Mustafa, A., Paena, M., Tarunamulia, \& Sammut, J. 2008. Hubungan antara faktor kondisi lingkungan dan produktivitas tambak untuk penajaman kriteria kesesuaian lahan: 2 . Kualitas tanah. Jurnal Riset Akuakultur, 3(1): 105-121.

Paquotte, P., Chim, L., Martin, J.-L.M., Lemos, E., Stern, M., \& Tosta, G. 1998. Intensive culture of shrimp Penaeus vannamei in floating cages: zootechnical, economic and environmental aspects. Aquaculture, 164: 151-166.

Parker, N.C. 1987. Feed conversion indices: controversy or convention. The Progressive Fish-Culturist, 49(3): 161-166.

Pathak, S.C., Ghosh, S.K., \& Palanisamy, K. 2000. The use of chemicals in aquaculture in India. In: Arthur, J.R., C.R. Lavilla-Pitogo and R.P. Subasinghe (Eds.), Use of Chemicals in Aquaculture in Asia. Southeast Asian Fisheries Development Center Aquaculture Department, Tigbauan, Iloilo, Philippines, $p$. 87-112.

Phillips, M. 2000. The use of chemicals in carp and shrimp aquaculture in Bangladesh, Cambodia, Lao PDR, Nepal, Pakistan, Sri Lanka and Viet Nam. In: Arthur, J.R., C.R. Lavilla-Pitogo and R.P. Subasinghe (Eds.), Use of Chemicals in Aquaculture in Asia. Southeast Asian Fisheries Development Center Aquaculture Department, Tigbauan, Iloilo, Philippines, p. 75-86.

Primavera, J.H. 1993. A critical review of shrimp pond culture in the Philippines. Rev. Fish. Sci., 1: 151-201.

Reddy, R., Pillai, B.R., \& Adhikari, S. 2006. Bioaccumulation of copper in post-larvae and juveniles of freshwater prawn 
Macrobrachium rosenbergii (de Man) exposed to sub-lethal levels of copper sulfate, Aquaculture, 252: 356-360.

Ringgo, E. 2002. Probiotics in aquaculture. In: Inui, Y. and E.R. Cruz-Lacierda (Eds.), Disease Control in Fish and Shrimp Aquaculture in Southeast Asia-Diagnosis and Husbandry Techniques. Southeast Asian Fisheries Development Center Aquaculture Department, Tigbauan, Iloilo, Philippines, p. 107-135.

Shariff, M., Nagaraj, G., Chua, F.H.C., \& Wang, Y.G. 2000. The use of chemicals in aquaculture in Malaysia and Singapore. In: Arthur, J.R., C.R. Lavilla-Pitogo, and R.P. Subasinghe (Eds.), Use of Chemicals in Aquaculture in Asia. Southeast Asian Fisheries Development Center Aquaculture Department, Tigbauan, Iloilo, Philippines, p. 127-141.

SPSS (Statistical Product and Service Solution). 2006. SPSS 15.0 Brief Guide. SPSS Inc., Chicago, $217 \mathrm{pp}$.

Subasinghe, R.P., Barg, U., \& Tacon, A. 2000. Chemicals in Asian aquaculture: need, usage, issues and challenges. In: Arthur, J.R., C.R. Lavilla-Pitogo and R.P. Subasinghe (Eds.), Use of Chemicals in Aquaculture in Asia. Southeast Asian Fisheries Development Center Aquaculture Department, Tigbauan, Iloilo, Philippines, p. 1-5.

Supriyadi, H. \& Rukyani, A. 2000. The use of chemicals in aquaculture in Indonesia. In: Arthur, J.R., C.R. Lavilla-Pitogo and R.P. Subasinghe (Eds.), Use of Chemicals in Aquaculture in Asia. Southeast Asian Fish- eries Development Center Aquaculture Department, Tigbauan, Iloilo, Philippines, p. 113-118.

Teichert-Coddington, D.R., Rouse, D.B., Potts, A., \& Boyd, C.E. 1999. Treatment of harvest discharge from intensive shrimp ponds by settling. Aquacultural Engineering, 19(3): 147-161.

Tonguthai, K. 2000. The use of chemicals in aquaculture in Thailand. In: Arthur, J.R., C.R. Lavilla-Pitogo and R.P. Subasinghe (Eds.), Use of Chemicals in Aquaculture in Asia. Southeast Asian Fisheries Development Center Aquaculture Department, Tigbauan, Iloilo, Philippines, p. 207-220.

Vijayram, K. \& Geraldine, P. 1996. Regulation of essential heavy metals ( $\mathrm{Cu}, \mathrm{Cr}$, and $\mathrm{Zn}$ ) by the freshwater prawn Macrobrachium malcolmsonii. Bull. Environ. Contam. Toxicol., 56: 335-342.

Widowati, W., Sastiono, A., \& Jusuf, R.R. 2008. Efek Toksik Logam: Pencegahan dan Penanggulangan Pencemaran. Penerbit Andi, Yogyakarta, $410 \mathrm{hlm}$.

Wirartha, I.M. 2006. Metodologi Penelitian Sosial Ekonomi. Penerbit Andi, Yogyakarta, 383 hlm.

Yulin, J. 2000. The use of chemicals in aquaculture in the People's Republic of China. In: Arthur, J.R., C.R. Lavilla-Pitogo and R.P. Subasinghe (Eds.), Use of Chemicals in Aquaculture in Asia. Southeast Asian Fisheries Development Center Aquaculture Department, Tigbauan, Iloilo, Philippines, p. 141-153. 